\title{
Sporcuların Yeni Tip Koronavirüse (COVID-19) Yakalanma Kaygı Düzeylerinin Bazı Değişkenler Açısından İncelenmesi
}

\author{
Aydıner Birsin YILDIZ ${ }^{1}$ (D) , Nilüfer ÇAT ${ }^{2}$ (D) , Gözde ALGÜN DOĞU \\ ${ }^{1}$ Ankara Yıldırım Beyazıt Üniversitesi Spor Bilimleri Fakültesi, ANKARA \\ ${ }^{2}$ Ankara Yıldırım Beyazıt Üniversitesi Sağlık Bilimleri Enstitüsü, ANKARA
}

Araştırma Makalesi

DOI:10.53434/gbesbd.958378

Öz

Bu araştırmanın amacı sporcuların COVID-19'a yakalanma kaygı düzeylerinin bazı değişkenler açısından incelenmesidir. Araştırmada kullanılan veriler kolay ulaşılabilir örneklem yöntemi ile 972 sporcunun (523 Kadın, 449 Erkek) dahil edildiği çalışma grubundan elde edilmiştir. Çalışma grubuna dâhil olmak için en az üç yıllık lisanslı sporcu olma, pandemi öncesinde en az bir yıldır resmi müsabakalara katılmış olma ve 17 ile 33 yaş aralığında olma kriterleri aranmıştır. Tarama modelinde yürütülmüş̧ betimsel araștırmada kullanılan veriler Demir, Cicioğlu ve İlhan (2020) tarafindan alanyazına kazandırılan "Sporcuların Yeni Tip Koronavirüse Yakalanma Kaygısı Ölçeği (SYTKYKÖ)" aracılı̆̆ıla elde edilmiştir. Elde edilen verilerin normal dağılım gösterdiği gözlemlenmiştir. Bu kapsamda bağımsız gruplar t-testi ve tek yönlü varyans analizi yapılmıștır. İstatistiksel analizler $p<0,05$ anlamlılık düzeyi dikkate alınarak SPSS 22 paket programı aracılığıyla yapılmıştır. Elde edilen sonuçlara göre sporcular cinsiyet, bireysel ve takım sporcusu olma, algılanan ekonomik durum değişkenleri açısından karşılaştırıldığında sporcuların COVID-19'a yakalanma kaygı düzeyleri istatistiksel olarak anlamlı bir biçimde farklılaşmaktadır. Öte yandan sporcuların COVID-19'a yakalanma kaygılarının bir yakınlarının COVID-19'a yakalanma değişkeni açısından farklılaşmadı̆̆ı da tespit edilmiştir. Sonuç olarak, sporcuların COVID-19'a yakalanma kaygısı içinde oldukları belirlenmiştir. Bu bilgilerden hareketle; sporcuların psikolojik yapılarının korunması ve sportif performans kayıplarının önüne geçilmesi amacıyla branș ve sporculuk seviyesi gözetmeksizin COVID-19'a yakalanma kaygıları da dahil olmak üzere sportif performanslarını olumsuz etkileyecek benzer unsurların farkında olunması ve bu unsurların giderilmesine yönelik çalışmaların yapılması önerilmektedir.

Anahtar sözcükler: COVID-19, Kaygı, Sporcu, Yeni tip koronavirüs 


\title{
Investigation of Athletes' Anxiety Levels of Novel Coronavirus (COVID-19) According to Some Variables
}

\begin{abstract}
The aim of this research is to examine the athlete's anxiety to catch the novel coronavirus (COVID-19) in terms of some variables. The study group of the research was composed of 972 (women=523, man=449) athletes who voluntarily participated with the easily accessible sampling method. In order to be included in the study group, the athletes were required to have at least three years of licensed sports and to participate in official competitions for at least one year before the pandemic, and being between the ages of 17 and 33 were determined as criteria. The data used in this study were obtained through the Novel Coronavirus Anxiety Scale developed by Demir, Cicioğlu, and IIlhan (2020). It was observed that the obtained data showed a normal distribution. In this context, independent groups $t$-test and one-way analysis of variance were performed. All analyzes were performed using the SPSS 22 package program, taking into account the significance level of $p<0,05$. According to the results, when the athletes are compared in terms of gender, being an individual and a team athlete, and economic evaluation variables, the levels of anxiety about catching a novel coronavirus differ significantly. On the other hand, it has been determined that the concerns of athletes about getting COVID-19 did not differ in terms of the variable of catching the COVID-19. As a result, it has been determined that the athletes are concerned about catching the COVID-19. Based on this information, it should be aware of similar factors that will negatively affect the sports performance of the athletes, including the anxiety of catching the COVID-19, regardless of the branch and level of sportsmanship.
\end{abstract}

Keywords: COVID-19, Anxiety, Athlete, Novel coronavirus

\section{Giriș}

Salgın, bir hastalığın bölge ya da toplumda beklenilenden daha fazla görülmesi olarak tanımlanırken (Hacımustafaoğlu, 2018); pandemi, salgın bir hastalığın dünya üzerinde kıtalar ve ülkeler seviyesinde yayılması olarak tanımlanmaktadır (Medipol, 2020). İnsanlık, tarihi akış içerisinde küresel düzeyde etkili olan veba, çiçek hastalığı, cüzzam, sıtma, kolera gibi salgın ve pandemi koşullarıyla zaman zaman karşı karşıya kalmıștır (Qiu, Rutherford, Mao ve Chu, 2016). Britanya Adaları'ndaki 664 Vebası (MÖ 668-664), Avrupa'daki Justinianus Vebası (MÖ 542-541), Atina'daki Antoninus Vebası (429-426), Kıbrıs'taki Veba (MÖ 266- 250), Avrupa, Asya ve Kuzey Afrika'yı etkisine alan Antoninus Vebası (180-165) yaşanılmış salgınlar arasındaki en önemlileri olarak değerlendirilmektedir (Aslan, 2020). İnsanlık bu ve benzeri durumların tekrarını yaşamamayı umut etse de gerçekte durum böyle olmamaktadır. Nitekim ilk olarak 2019 yılının Aralık ayında ortaya çıkan ve 2020 yılının Ocak ayında tanımlanan yeni bir pandemiyle karşı karşıya kalmıştır. Bu seferki pandeminin kaynağının ise yeni tip bir koronavirüs olduğu (2019-nCoV) açıklanmış ve bu yeni virüs, "SARS-CoV-2" olarak literatüre geçmştir (WHO, 2020). COVID-19 olarak kullanımı yaygınlık gösteren yeni tip koronavirüsün, diğer koronavirüs türlerine göre ölüm oranının daha az olarak tanımlanmasına rağmen, bulaş düzeyinin ise daha yüksek olduğu ifade edilmiştir (Liu, Gayle, Wilder-Smith ve Rocklöv, 2020). Bu durum virüsün kısa sürede bir pandemiye dönüşmesinin sebepleri arasında gösterilmektedir. 
COVID-19, ağır akut solunum sendromu (SARS) ve orta doğu solunum sendromu (MERS) gibi şiddetli ve akut hastalıklara neden olan, koronavirüs ailesinin mutasyonlu yeni üyesidir (Brown ve Wang, 2020). COVID-19, solunum sistemini hedef almaktadır ve yaygın semptomları olarak ateș, halsizlik, öksürük ve miyalji sayılmaktadır (Lu vd., 2020). COVID19, doğrudan temas ya da enfekte bir kișiden yayılan damlacıklar aracılığıyla bulaşmaktadır. Bu damlacık aktarımı kişiden kişiye doğrudan olabileceği gibi, damlacı̆̆a sahip olunan yüzeye yapılan temasla da gerçekleşebilmektedir (Chen vd., 2020). Bu virüsün sebep olduğu pandeminin üstesinden gelebilmek amacıyla tüm dünyada olduğu gibi Türkiye'de de 2020 yılında ve Mart ayında tespit edilen ilk vaka ile aşamalı olarak çeşitli önlemler alınmaya başlanmıştır. Bu önlemler, birey ile toplum arasında gerçekleştirilen tam ya da kısmi temas yoksunluğu durumu olarak tanımlanan sosyal izolasyon (Gierueld, Tilburg ve Dvkstra, 2006) temelinde yürütülmüş ve bu kapsamda sokağa çıkma yasağı, organizasyonların iptal edilmesi gibi uygulamalar hayata geçirilmiştir. Bu kapsamda tüm insanlığın içinde sporcuların da etkilendiği bir ortam oluşmuştur. Sportif faaliyetlerin tamamının durdurulması, antrenman ve müsabakaların ertelenmesi, iptal edilmesi gibi koşulların sporcular üzerinde ekonomik, sosyolojik ve psikolojik etkileri olmuştur. Sporcular antrenman yapamadıkları için performans kaybı yaşayacaklarından ve gelecekteki müsabakalarını kaybedeceklerinden endişe etmeye başlamışlardır. Bu tarz düşünceler de sporcuların belirsizlik kaynaklı gerginlik ve kaygı yaşamalarına neden olmuştur.

Kaygı, gelecek için endişe etme temelinde yaşanır ve kişinin yaşamı ve geleceği için hissettiği tehdide karşı oluşturulan gerginlik ve endişe hali olarak tanımlanan olumsuz duygu durumlarıdır (Passer ve Smith, 2012). Mevcut koşullar da sporcuların COVID-19 pandemisini bir tehdit olarak tanımlamasına ve bu duruma karşı olumsuz duygu durumları içerisinde olmasına neden olmaktadır. Bu durum, sporcuların COVID-19'a yakalanma kaygı düzeylerinin araştırılmasına yönelik bir gerekçe oluşturmaktadır.

Sporcuların psikolojik yapıları her ne kadar pandemi öncesinde araştırmacılar tarafından incelenmiş olsa da (Arı vd., 2020; Çiftçi, Tolukan ve Yılmaz, 2021; Gülşen, Yıldız, Yılmaz ve Şahan, 2019; Tolukan ve Akyel, 2019; Tolukan ve Yılmaz, 2020; Yarayan ve Ayan, 2018; Yarayan, Yıldız ve Gülșen, 2018; Yıldız, Algün Doğu, Parlakkılıç Büyükakgül ve Yaman Yılmaz, 2020) sporun kitlesel etki gücü dikkate alınarak COVID-19 sürecinin sporcular üzerindeki etkilerine yönelik daha fazla araştırmaya ihtiyaç duyulmaktadır (Koçak, Özer Kaya, 2020).

$\mathrm{Bu}$ kapsamda bu araştırmanın COVID-19'un sporcular üzerindeki psikolojik etkilerinden olan kaygı düzeylerinin anlaşılmasına katkı sağlayacağını ve bu doğrultuda sporcuların pandemi sürecinden en az hasarla çıkabilmesine yönelik önlemlerin alınması adına bir farkındalık oluşturacağı düşünülmektedir. Bu kapsamda bu araştırmada, sporcuların COVID-19'a yakalanma kaygılarının cinsiyet, spor türü, yakının COVID-19 geçirme durumu ve algılanan ekonomik durum açısından incelenmesi amaçlanmıştır. Araştırmanın branş çeşitliliği, ele alınan değiş̧kenleri ve katılımcı sayısı ile araştırma bulgularının ve yapılacak raporlamanın ilgili alanyazına katkı sağlayacağı düşünülmektedir. 


\section{Yöntem}

Araştırma Modeli

Bu araștırma, sporcuların COVID-19'a yakalanma kaygı düzeylerinin bazı değişsenler açısından incelenmesini amaçlayan tarama modelinde yürütülmüş betimsel bir araştırmadır. Tarama modeli araştırmalarında güncel ya da geçmiş bir durumun mevcut haliyle, değiștirilmeden ortaya konulması amaçlanmaktadır (Karasar, 2008).

Araştırmada pratikliğinden ve ekonomikliğinden dolayı tercih edilen kolay ulaşlabilir örnekleme yönteminden faydalanılmıştır. Bu yöntem, araştırma grubunun yakın ve erișilmesi kolay bireylerden oluşturulması yöntemidir (Yıldırım ve Şimșek, 2016).

Araştırma Grubu

Araştırma grubunu, gönüllülükle araştırmaya dâhil olan 972 sporcu olușturmuştur. Çalışma grubuna dâhil olmak için en az üç yıllık lisanslı sporcu olma, pandemi öncesinde en az bir yıldır resmi müsabakalara katılmış olma ve 17 ile 33 yaş aralığında olma kriterleri esas alınmıştır. Bu kapsamda oluşturulan çalışma grubunun yaş ortalaması $22,63 \pm 5,6$ 'dır. Araștırmanın çalışma grubunu olușturan sporcuların bazı demografik bilgileri Tablo 1'de verilmiştir.

Tablo 1. Katılımcıların demografik bilgilerine ilişkin veriler

\begin{tabular}{lccc}
\hline Demografik Bilgiler & Değişken & N & \% \\
\hline \multirow{2}{*}{ Cinsiyet } & Kadın & 523 & 53,8 \\
& Erkek & 449 & 46,2 \\
\hline \multirow{2}{*}{ Branş } & Takım & 299 & 30,8 \\
& Bireysel & 673 & 69,2 \\
\hline \multirow{2}{*}{ Algılanan Ekonomik Durum } & Düşük & 207 & 21,3 \\
& Orta & 657 & 67,6 \\
\hline \multirow{2}{*}{ Bir Yakınının } & Yüksek & 108 & 11,1 \\
COVID-19 Geçirme Durumu & Evet & 363 & 37,3 \\
\hline
\end{tabular}

Tablo 1 incelendiğinde, araştırma grubunun \%53,8'i kadın, \%46,2'si erkek; \%30,8'i takım (voleybol, hentbol) sporcusu, \%69,2'si bireysel (judo, tekvando) sporcudur. Ayrıca, algılanan ekonomik durum \%21,3'ü için düşük, \%67,6'sı için orta, \%11,1'i için yüksektir. Pandemi süresince \%37,3'sinin bir yakını COVID-19 geçirmiştir. Sporcular arasında COVID-19 geçiren bulunmamaktadır.

\section{Veri Toplama Araçları}

Analizlerde kullanılan veriler, bazı demografik bilgileri içeren "Kişisel Bilgi Formu" ve "Sporcuların Yeni Tip Koronavirüse Yakalanma KaygıSı Ölçeği (SYTKYKÖ)" aracıllğııla toplanmıştır. Sporcuların Yeni Tip Koronavirüse Yakalanma Kaygısı Ölçeği, Demir, Cicioğlu ve İlhan (2020) tarafından alanyazına kazandırılmıștır. Bireysel kaygı ve sosyalleșme kaygısı olarak adlandırılan iki alt boyutu bulunan ölçek, 5 dereceli likert tipi 
değerlendirmeye tabi 16 maddeden oluşmaktadır. Bireysel kaygı "korku duyulan bir durum karşısında kaygı ve tedirginlik yaratan duyguların ortaya çıkması" olarak tanımlanırken; sosyalleșme kaygısı ise "korku duyulan vakalarda sosyalleşme durumundan kaygı duyulması ve sosyalleşmeden kaçınma yaşanması" olarak tanımlanmıştır. Ölçekten elde edilen yüksek puanlar, yüksek kaygıyı ifade etmektedir ve "kaygı durumu yükseldikçe psikolojik açıdan sağlıksız olma durumunun arttı̆̆ı" ifade edilmektedir (Demir vd., 2020).

\section{Verilerin Analizi}

Araştırma kapsamında elde edilen yanıtların iç tutarlılıkları Cronbach Alpha katsayısı ile değerlendirilmiş ve bireysel kaygı alt boyutu için 0,89, sosyalleşme kaygısı için 0,83, ölçeğin tamamı için ise 0,91 olduğu saptanmıştır. Elde edilen verilerin dağılımları histogram, q-plot grafikleri ile basıklık ve çarpıklık değerleriyle incelenmiş ve normal dağılım gösterdiği tespit edilmiştir. Bu kapsamda bağımsız gruplar t-testi ve tek yönlü varyans analizi uygulanmıştır. Tüm analizler $\mathrm{p}<0,05$ anlamlılık düzeyi dikkate alınarak SPSS 22 paket programı aracılığıyla uygulanmıştır.

\section{Bulgular}

Sporcuların, SYTKYKÖ'den ve alt boyutlarından almış oldukları puanların cinsiyet değişkeni açısından karşılaştırılmasına yönelik yapılan t-testi sonuçları Tablo 2'de görülmektedir.

Tablo 2. Cinsiyete göre bağımsız gruplar t-testi sonuçları

\begin{tabular}{|c|c|c|c|c|c|c|}
\hline Boyutlar & Cinsiyet & $\mathbf{N}$ & $\overline{\mathbf{X}}$ & Ss & $\mathbf{t}$ & $p$ \\
\hline \multirow{2}{*}{ Bireysel Kaygilar } & Kadın & 523 & 40,28 & 8,30 & \multirow{2}{*}{5,02} & \multirow{2}{*}{0,00} \\
\hline & Erkek & 449 & 37,43 & 9,24 & & \\
\hline \multirow{2}{*}{ Sosyalleşme Kaygısı } & Kadın & 523 & 15,64 & 4,48 & \multirow{2}{*}{1,64} & \multirow{2}{*}{1,00} \\
\hline & Erkek & 449 & 15,14 & 4,97 & & \\
\hline \multirow{2}{*}{ SYTKYKÖ } & Kadın & 523 & 55,93 & 11,38 & \multirow{2}{*}{4,21} & \multirow{2}{*}{0,00} \\
\hline & Erkek & 449 & 52,57 & 13,15 & & \\
\hline
\end{tabular}

SYTKYKÖ: Sporcuların Yeni Tip Koronavirüse Yakalanma Kaygı Ölçeği, ${ }^{*} p<0,05$

Tablo 2 incelendiğinde, bireysel kaygılar alt boyutunda kadın sporcuların $(\bar{x}=40,28 \pm 8,30)$, erkek sporculara $(\bar{x}=37,43 \pm 9,24)$ kıyasla anlamlı biçimde daha yüksek kaygı puanına sahip oldukları görülmüştür $(t=5,02 ; p<0,05)$. Ayrıca SYTKYKÖ toplam puanı açısından da kadın sporcuların $(\bar{x}=55,93 \pm 11,39)$, erkek sporculara $(\bar{x}=52,57 \pm 13,15)$ kıyasla anlamlı biçimde daha yüksek kaygı puanına sahip oldukları görülmektedir $(\mathrm{t}=4,21$; $\mathrm{p}<0,05$ ).

Sporcuların, SYTKYKÖ'den ve alt boyutlarından almış oldukları puanların spor türü açısından karşılaştırılmasına yönelik yapılan t-testi sonuçları Tablo 3'te görülmektedir. 
Tablo 3. Spor türüne göre bağımsız gruplar t-testi sonuçları

\begin{tabular}{lcccccc}
\hline Boyutlar & Branş & $\mathbf{N}$ & $\overline{\mathbf{X}}$ & Ss & $\mathbf{t}$ & $\boldsymbol{p}$ \\
\hline \multirow{2}{*}{ Bireysel Kaygılar } & Takım & 299 & 40,66 & 7,51 & \multirow{2}{*}{0,33} & 0,00 \\
& Bireysel & 673 & 38,22 & 9,30 & & \\
\hline \multirow{2}{*}{ Sosyalleșme Kaygısı } & Takım & 299 & 15,50 & 4,08 & \multirow{2}{*}{444} & 0,65 \\
& Bireysel & 673 & 15,37 & 4,98 & & \\
\hline \multirow{2}{*}{ SYTKYKÖ } & Takım & 299 & 56,16 & 10,33 & \multirow{2}{*}{3,27} & 0,01 \\
& Bireysel & 673 & 53,39 & 13,02 & & \\
\hline
\end{tabular}

SYTKYKÖ: Sporcuların Yeni Tip Koronavirüse Yakalanma Kaygı Ölçeği, * $p<0,05$

Tablo 3 incelendiğinde, bireysel kaygılar alt boyutunda takım sporcularının $(\bar{x}=40,66 \pm 7,51)$, bireysel sporculara $(\bar{x}=38,22 \pm 9,30)$ kıyasla anlamlı biçimde daha yüksek kaygı puanına sahip oldukları görülmüştür $(\mathrm{t}=4,33 ; \mathrm{p}<0,05)$. Ayrıca SYTKYKÖ toplam puanı açısından da takım sporcularının $(\bar{x}=56,16 \pm 10,33)$, bireysel sporculara $(\bar{x}=53,59 \pm 13,02)$ kıyasla anlamlı biçimde daha yüksek kaygı puanına sahip oldukları görülmüştür $(\mathrm{t}=3,27$; $\mathrm{p}<0,05)$.

Sporcuların, SYTKYKÖ'den ve alt boyutlarından almış oldukları puanların bir yakınının COVID-19 geçirme durumuna göre karşılaştırılmasına yönelik yapılan t-testi sonuçları Tablo 4'te görülmektedir.

Tablo 4. Yakınının COVID-19 geçirme durumuna göre bağımsız gruplar t-testi sonuçları

\begin{tabular}{lcccccc}
\hline Boyutlar & COVID-19 & $\mathbf{N}$ & $\overline{\mathbf{X}}$ & Ss & $\mathbf{t}$ & $\boldsymbol{p}$ \\
\hline \multirow{2}{*}{ Bireysel Kaygılar } & Evet & 363 & 38,39 & 8,84 & \multirow{2}{*}{0} & \multirow{2}{*}{0,12} \\
& Hayır & 609 & 39,31 & 8,86 & & \\
\hline \multirow{2}{*}{ Sosyalleşme Kaygısı } & Evet & 363 & 15,14 & 4,59 & \multirow{2}{*}{1,35} & 0,18 \\
& Hayır & 609 & 15,56 & 4,79 & & \\
\hline \multirow{2}{*}{ SYTKYKÖ } & Evet & 363 & 53,54 & 12,28 & \multirow{2}{*}{0,64} & 0,10 \\
& Hayır & 609 & 54,88 & 12,36 & & \\
\hline
\end{tabular}

SYTKYKÖ: Sporcuların Yeni Tip Koronavirüse Yakalanma Kaygı Ölçeği, * $p<0,05$

Tablo 4 incelendiğinde, sporcuların COVID-19'a yakalanma kaygı düzeylerinin, bir yakınının COVID-19'a yakalanma durumlarına göre istatistiksel olarak anlamlı bir biçimde farklılaşmadığı görülmüştür.

Sporcuların, SYTKYKÖ'den ve alt boyutlarından almış oldukları puanların algılanan ekonomik durum değişkeni açısından karşılaştırılmasına yönelik yapılan tek yönlü varyans analizi sonuçları Tablo 5'te görülmektedir. 
Tablo 5. Algılanan ekonomik durum değişkenine göre ANOVA testi sonuçları

\begin{tabular}{lccccccc}
\hline Boyutlar & Ekonomik & $\mathbf{N}$ & $\overline{\mathbf{X}}$ & Ss & $\mathbf{t}$ & $\boldsymbol{p}$ & $\begin{array}{c}\text { İkili } \\
\text { Karşıslaştırma }\end{array}$ \\
\hline \multirow{3}{*}{ Bireysel Kaygılar } & Düşük $^{1}$ & 207 & 41,23 & 8,30 & & & $1>2$ \\
& Orta $^{2}$ & 657 & 38,79 & 8,47 & 14,43 & 0,00 & $1>3$ \\
& Yüksek $^{3}$ & 108 & 35,74 & 10,90 & & & $2>3$ \\
\hline \multirow{3}{*}{ Sosyalleşme Kaygısl } & Düşük $^{1}$ & 207 & 16,48 & 4,72 & & & \\
& Orta $^{2}$ & 657 & 15,23 & 4,58 & 8,29 & 0,00 & $1>2$ \\
& Yüksek $^{3}$ & 108 & 14,41 & 5,21 & & & $1>3$ \\
SYTKYKÖ & Düşük $^{1}$ & 207 & 57,71 & 11,77 & & & $1>2$ \\
& Orta $^{2}$ & 657 & 54,02 & 11,73 & 14,53 & 0,00 & $1>3$ \\
& Yüksek $^{3}$ & 108 & 50,15 & 15,21 & & & $2>3$
\end{tabular}

SYTKYKÖ: Sporcuların Yeni Tip Koronavirüse Yakalanma Kaygı Ölçeği, * $p<0,05$

Tablo 5 incelendiğinde, SYTKYKÖ toplam puanı ve bireysel kayglar alt boyutunda algılanan ekonomik durumunu düşük olarak tanımlayan sporcuların $\left(\mathrm{x}^{-}=57,71 \pm 11,77\right.$; $\bar{x}=41,23 \pm 8,30)$, orta $(\bar{x}=54,02 \pm 11,73 ; \quad \bar{x}=38,79 \pm 8,47)$ ve yüksek $(\bar{x}=50,15 \pm 15,21$; $\bar{x}=35,74 \pm 10,90$ ) olarak değerlendiren sporculara kıyasla istatistiksel olarak anlaml biçimde daha yüksek COVID-19'a yakalanma kaygı puanına sahip oldukları görülmüştür $(\mathrm{F}=14,53 ; \mathrm{p}<0,05 ; \mathrm{F}=14,43 ; \mathrm{p}<0,05)$.

Ayrıca algılanan ekonomik durumunu orta olarak tanımlayan sporcular $(\bar{x}=54,02 \pm 11,73 ; \bar{x}=38,79 \pm 8,47)$ ile yüksek olarak tanımlayan sporcular $(\bar{x}=50,15 \pm 15,21$; $\bar{x}=35,74 \pm 10,90$ ) arasında da ekonomik gelirini orta düzey olarak tanımlayan sporcuların yüksek olarak tanımlayan sporculara kıyasla istatistiksel olarak anlamlı bir biçimde daha yüksek COVID-19'a yakalanma kaygı puanına sahip olduğu belirlenmiștir ( $F=14,53$; $\mathrm{p}<0,05 ; \mathrm{F}=14,43 ; \mathrm{p}<0,05$ ).

Bununla birlikte sosyalleşme kaygısı alt boyutunda da algılanan ekonomik durumunu düşük olarak tanımlayan sporcuların $(\bar{x}=16,48 \pm 4,72)$, orta $(\bar{x}=15,23 \pm 4,58)$ ve yüksek olarak değerlendiren sporculara $(\bar{x}=14,41 \pm 5,21)$ kıyasla COVID-19'a yakalanma kaygı puanlarının istatistiksel olarak anlamlı biçimde daha yüksek olduğu görülmüştür ( $F=8,29$; $\mathrm{p}<0,05)$.

\section{Tartışma ve Sonuç}

Sporcuların COVID-19'a yakalanma kaygılarının bazı değişkenlere göre incelendiği bu araştırmada elde edilen sonuçlara göre, sporcuların cinsiyet değişkeni açısından bireysel kaygılar alt boyutu ile COVID-19'a yakalanma kaygısı toplam puanına göre istatistiksel olarak anlamlı bir biçimde farklılaştığı görülmüştür. Elde edilen anlamlı farklılıkta ise kadın sporcuların kaygı düzeylerinin yüksek olduğu saptanmıştır.

İlgili alanyazın incelendiğinde, Türktemiz, Bayraktar, Çobanoğlu ve Nalbant (2020) raporlamış olduğu sonuçlar araştırma sonuçlarıyla benzerlik göstermektedir. İlgili araştırmanın sonuçlarında da cinsiyet değişkeni açısından bireysel kaygı alt boyutunda 
kadın sporcuların istatistiksel olarak anlamlı bir șekilde daha yüksek puana sahip oldukları tespit edilmiştir.

Başka bir araştırmada Batu ve Aydın (2020), COVID-19'a yakalanma kaygıları toplam puanını ve bireysel kaygı alt boyutunun cinsiyet değișkeni açısından istatiksel olarak farklılaştığını belirlemişlerdir. Elde edilen farklılığın da benzer şekilde kadınların daha yüksek puanlara sahip olmasından kaynaklandığını raporlamışlardır. Güler ve Cicioğlu (2021) tarafından yürütülmüş bir diğer araștırmada da cinsiyetin COVID-19'a yakalanma kaygısı açısından bir belirleyici olduğu ve kadınların COVID-19'a yakalanma kaygılarının istatistiksel olarak anlamlı bir biçimde daha yüksek olduğu belirlenmiştir. COVID-19 pandemisi döneminde Spor Bilimleri Fakültesi öğrencilerinin kaygı düzeyleri üzerine yapılmış bir araştırmada ise, benzer şekilde cinsiyetin istatistiksel olarak bir farklılık kaynağı olduğu ve bu farklılığın kadınların daha yüksek kaygı düzeylerine sahip olmaları yönünde olduğu belirlenmiştir (Acar, Mor, Baynaz ve Arslanoğlu, 2020). Farklı bir çalışma sonuçları da pandemiden kaynaklanan depresyon ve anksiyetenin kadın sporcularda istatistiksel olarak anlamlı bir biçimde daha yaygın olarak gözlemlendiğini raporlamıștır (Håkansson, Jönsson ve Kenttä, 2020; Sakaoğlu, Orbatu, Emiroglu ve Çakır, 2020).

Tüm bu araştırmalara ek olarak mevcut pandemi öncesinde de kadınların erkeklere kıyasla daha yüksek kaygı düzeyine sahip olduğu (Alexander, Dennerstein, Kotz ve Richardson, 2007) ve mevcut pandemideki kaygı bozukluğu şikayetlerinin erkeklere kıyasla kadınlarda üç kata kadar daha fazla gözlemlendiği (Wang, Di, Ye ve Wei, 2020) dikkate alındığında, araştırma sonuçlarının ilgili alanyazınla paralellik gösterdiği söylenebilir. Kadınların COVID-19'a yakalanma kaygı düzeylerinin erkeklere kıyasla daha yüksek olmasının temel nedeninin daha net ifade edilebilmesi amacıyla daha fazla araştırmaya ihtiyaç olmasıyla birlikte, bu durumun kadınların duygusal ve psikolojik yapılarıyla birlikte kadının aile içindeki ve toplumdaki sorumluluklarından ve rollerinden kaynaklandığı düşünülebilir.

Araştırma kapsamında elde edilen bir diğer tespit ise, sporcuların spor türü açısından bireysel kaygılar alt boyutu ile COVID-19'a yakalanma kaygısı toplam puanına göre istatistiksel olarak anlamlı bir biçimde farklılaştığıdır. Tespit edilen bu farklılıkta ise takım sporcularının bireysel sporculara kıyasla kaygı düzeylerinin daha yüksek olduğu belirlenmiştir. Sınırlı alanyazın incelendiğinde, araştırma sonuçlarıyla farklılık gösteren sonuçlar (Yıldız, 2020) ile birlikte araştırma sonuçlarıyla benzerlik gösteren çalışmalar da bulunmaktadır. İlgili araştırmada bireysel ya da takım sporu yapma değişkeni açısından takım sporcularının istatistiksel olarak anlamlı bir şekilde daha yüksek COVID-19'a yakalanma kaygı puanlarına sahip oldukları belirlenmiştir (Ağduman, 2021).

$\mathrm{Bu}$ sonuçlardan yola çıkarak takım sporcularının, bir takımın üyesi olmasından kaynaklı olarak gerek antrenmanlarını gerekse müsabakalarını birden fazla kişinin içerisinde bulunduğu ortamlarda yapmak durumunda olmasından dolayı; temas temelli bulaşıcılığı bulunan COVID-19'a yakalanma kaygılarının daha yüksek olduğu düşünülmektedir. 
Takım sporlarının gerek katılımcı sayısı gerekse daha fazla temas içermesinden dolayı takım sporcularının bireysel sporculara kıyasla daha yüksek COVID-19'a yakalanma kaygıları taşımalarının kabul edilebilir olduğu düşünülmektedir. Bu yöndeki düşüncelerin ise araştırma sonuçlarında elde edilen takım sporcularının bireysel sporculara kıyasla daha yüksek COVID-19'a yakalanma kaygısı içerisinde olmalarına gerekçe olabileceği söylenebilir. Araștırma kapsamında ayrıca sporcuların COVID-19'a yakalanma kaygı durumlarının, bir yakınının COVID-19'a yakalanma durumlarına göre istatistiksel olarak anlamlı bir biçimde farklılaşmadığı görülmüştür. Özdin ve Bayrak Özdin (2020)'nin yürütmüş oldukları çalışmalarının sonuçlarında da bireyin bir arkadaşının ya da yakınının COVID-19'a yakalanmış olmaları ile hissedilen kaygı arasında istatistiksel olarak anlamlı bir ilişki olmadı̆̆ı tespit edilmiştir. Araştırma sonuçlarında ayrıca bir arkadaş ya da bir yakının COVID-19'a yakalanma durumunun, kaygının bir belirleyicisi olmadığı raporlanmıştır. Bu tespitin, COVID-19'un bulaşma koşulları doğrultusunda alınan mevcut pandemi önlemleri bağlamında açıklanabileceği düşünülmektedir. Mevcut koşullarda bireylerin buluşmalar ve ziyaretler gibi bir araya gelme durumlarından kaçındıkları göz önüne alındığında, bir tanıdığın COVID-19'a yakalanması ile bireyin yaşayacağı kaygı düzeyinin ilişki içerisinde olmayacağının kabul edilebilir olduğu düşünülmektedir. Nitekim pandemi koşullarında bireylerin genel kaygı ve COVID-19'a yakalanma kaygı düzeylerinin temelde kişisel değerlendirmeler temelinde belirleneceği söylenebilir.

Araștırma kapsamında elde edilen bir diğer bulgu ise, sporcuların COVID-19'a yakalanma kaygı düzeylerinin algılanan ekonomik durumuna göre istatistiksel olarak farklılaştığıdır. Bu bulgulara göre sporcuların COVID-19'a yakalanma kaygıları, algılanan ekonomik durum arttıkça azalmaktadır. Diğer bir ifadeyle sporculardan, algılanan ekonomik durumlarını düşük olarak değerlendirenlerin COVID-19'a yakalanma kaygıları daha yüksektir. Aksu (2018)'nun elde ettiği bulgular da sonuçlarımızla paralellik göstermektedir. Bu çerçevede yapılan araştırmaların sonuçlarının değerlendirilmesinde araştırma grubunun demografik özellikleri dikkate alınmalıdır. Araştırma grubundaki sporcuların, sporculuk seviyeleri ve branşlarının ülkemiz genelindeki ekonomik koşulları dikkate alındığında elde edilen sonuçların kabul edilebilir olduğu düşünülmektedir. Olası bir COVID-19'a yakalanma neticesinde gerek tedavi masraflarının ortaya çıkması gerekse de sporculuk gelirlerinin azalması gibi durumlarla karşılaşılabileceklerinden kaygı düzeylerinin farklılaşması söz konusu olabilir. Bu bağlamda ekonomik gelir düzeyinin COVID-19'a yakalanma kaygısı üzerinde bir belirleyici olacağı söylenebilir.

Sonuç olarak, sporcuların COVID-19'a yakalanma kaygısı içinde olduğu belirlenmiştir. Ayrıca sporcuların içinde bulunduğu bu kaygı durumunun bazı belirleyicilerine yönelik kanıtlar oraya konmuştur. Bu bilgilerden hareketle; sporcuların psikolojik yapılarının korunması ve sportif performans kayıplarının önüne geçilmesi amacıyla branş ve sporculuk seviyesi gözetmeksizin sporcuların COVID-19'a yakalanma kaygıları da dahil olmak üzere sportif performanslarını olumsuz etkileyecek benzer unsurların farkında olunması ve bu unsurların giderilmesine yönelik çalışmaların yapılması önerilmektedir. 


\section{Çıkar Çatışması}

$\mathrm{Bu}$ makalenin yayınlanmasıyla ilgili yazarlar arasında herhangi bir çıkar çatışması bulunmamaktadır.

\section{Yazar Katkıları}

Araştırma Fikri: ABY, NÇ, GAD; Araştırma Tasarımı: GAD; Verilerin Analizi: ABY; Makale Yazımı: ABY, NÇ, GAD; Eleştirel İnceleme: ABY, GAD

\section{Yazıșma Adresi (Corresponding Address):}

Arş. Gör. Dr. Aydıner Birsin YILDIZ

Ankara Yıldırım Beyazıt Üniversitesi Spor Bilimleri Fakültesi, ANKARA

ORCID: 0000-0002-3767-1057

E-posta: aydinerbirsinyildiz@hotmail.com 


\section{Kaynaklar}

1. Acar, K., Mor, A., Baynaz, K. ve Arslanoğlu, E. (2020) An investigation on anxiety states of students in faculty of sport sciences during COVID-19. International Journal of Disabilities Sports and Health Sciences, 3(1), 66-73.

2. Ağduman, F. (2021). Sporcuların pandemi döneminde COVID-19'a yakalanma kaygı düzeylerinin incelenmesi. GERMENiCA Beden Eğitimi ve Spor Bilimleri Dergisi, 2(1), 1-14.

3. Aksu, 0. (2018). Karate sporcularının sürekli kaygı düzeyleri, duygusal zekâ ve kişsilik özelliklerinin çeşitli değişkenlere göre belirlenmesi (Yayımlanmamış yüksek lisans tezi). Bartın Üniversitesi Eğitim Bilimleri Enstitüsü, Bartın.

4. Alexander, J. L., Dennerstein, L., Kotz, K. ve Richardson, G. (2007). Women, anxiety and mood: a review of nomenclature, comorbidity and epidemiology. Expert Review of Neurotherapeutics, $7(11), 45-58$.

5. Arı, C.., Ulun, C., Yarayan, Y. E., Dursun, M., Mutlu, T. ve Üstün, Ü. D. (2020). Mindfulness, healthy life skills and life satisfaction in varsity athletes and university students. Progress in Nutrition, 22(2), e2020024.

6. Aslan, R. (2020). Tarihten günümüze epidemiler, pandemiler ve COVID-19. Ayrıntı Dergisi, 8(85), 35-41.

7. Batu, B. ve Aydın, A. D. (2020). Yüzme sporcularının yeni tip korona virüse (COVID-19) yakalanma kaygısının incelenmesi. Uluslararası Hakemli Akademik Spor Sağlık ve Tıp Bilimleri Dergisi, 3, 12-31.

8. Brown, K. ve Wang, R. C. (2020). Politics and science: The case of China and the coronavirus. Asian Affairs, 51(2), 247-264.

9. Chen, N., Zhou, M., Dong, X., Qu, J., Gong, F., Han, Y. et al. (2020). Epidemiological and clinical characteristics of 99 cases of 2019 novel coronavirus pneumonia in Wuhan, China: a descriptive study. The Lancet, 395(10223), 507-513.

10. Çiftçi, M. C., Tolukan, E. ve Yılmaz, B. (2021). Sporcuların zihinsel antrenman becerileri ile sürekli sportif öz güven düzeyleri arasındaki ilişki. Gazi Beden Eğitimi ve Spor Bilimleri Dergisi, 26(1), 151-162.

11. Gierueld, J. D. J., Tilburg, T. V. ve Dvkstra, P. A. (2006). Loneliness and social ssolation. The Cambridge Handbook of Personal Relationships, 485-500.

12. Güler, H. ve Cicioğlu, H. İ. (2021). Sedanter ve sporcuların yeni tip koronavirüse yakalanmada bireysel kaygı düzeylerinin incelenmesi. Journal of Human Sciences, 18(1), 67-75.

13. Gülşen, D. B. A., Yıldız, A. B., Yılmaz, B. ve Şahan, H. (2019). Spor bilimleri fakültesindeki öğrencilerin kendinle konuşma ve zihinsel dayanıklılı düzeyleri arasındaki ilişkinin incelenmesi. Gaziantep Üniversitesi Spor Bilimleri Dergisi, 4(4), 459-470.

14. Hacımustafaoğlu, M. (2018). Enfeksiyon hastalıkları pratiğinde salgın tanımlanması, Cocuk Enfeksiyonları Dergisi, 12(4), 172-173.

15. Håkansson, A., Jönsson, C. ve Kenttä, G. (2020). Psychological distress and problem gambling in elite athletes during COVID-19 restrictions-a web survey in top leagues of three sports during the pandemic. International Journal of Environmental Research and Public Health, 17(18), 6693.

16. Karasar, N. (2008). Bilimsel araștırma yöntemi. Ankara: Nobel Yayın Dağıtım.

17. Koçak, U. ve Özer Kaya, D. (2020). COVID-19 pandemisi, spor, sporcu üçgeni: etkilenimler ve öneriler. İzmir Katip Çelebi Üniversitesi Sağlık Bilimleri Fakültesi Dergisi, 5(2), 129-133.

18. Liu, Y., Gayle, A. A., Wilder-Smith, A. ve Rocklöv, J. (2020). The reproductive number of covid19 is higher compared to sars coronavirus. Journal of Travel Medicine, 27(2), 1-4. 
19. Lu, R., Zhao, X., Li, J., Niu, P., Yang, B., Wu, H. et al. (2020). Genomic characterisation and epidemiology of 2019 novel coronavirus: implications for virus origins and receptor binding. The Lancet, 395(10224), 565-574.

20. Medipol (2020). Pandemi nedir? Corona virüsü neden pandemi ilan edildi? Erişim adresi: https://medipol.com.tr/bilgi-kosesi/bunlari-biliyor-musunuz/pandemi-nedir-corona-virusuneden-pandemi-ilan-edildi

21. Özdin, S. ve Bayrak Özdin, Ş. (2020). Levels and predictors of anxiety, depression and health anxiety during COVID-19 pandemic in Turkish society: the importance of gender. International Journal of Social Psychiatry, 66(5), 504-511.

22. Passer, M. W. ve Smith, R. E. (2012). Psychology: The science of mind and behavior. Boston: Mcgraw-Hill Higher Education.

23. Qiu, W., Rutherford, S., Mao, A. ve Chu, C. (2016). The pandemic and its impacts. Health, Culture and Society, 9, 1-11.

24. Sakaoğlu, H. H., Orbatu, D., Emiroglu, M. ve Çakır, Ö. (2020). COVID-19 salgını sırasında sağlık çalışanlarında Spielberger durumluk ve sürekli kaygı düzeyi: Tepecik Hastanesi örneği. Tepecik Eğitim ve Araştırma Hastanesi Dergisi, 30(Ek sayı), 1-9.

25. Tekkurşun Demir, G., Cicioğlu, H. İ. ve İlhan, E. L. (2020). Sporcuların yeni tip koronavirüse (COVID-19) yakalanma kaygısı ölçeği (SYTKYKÖ): Geçerlik ve güvenirlik çalışması. Journal of Human Sciences, 17(2), 458-468.

26. Tolukan, E. ve Akyel, Y. (2019). Futbolda antrenör-sporcu ilişkisi ve sürekli sportif kendine güven üzerine bir araştırma. SPORMETRE Beden Eğitimi ve Spor Bilimleri Dergisi, 17(1), 103-112.

27. Türktemiz, H., Bayraktar, I., Çobanoğlu, H. O. ve Nalbant, Ö. (2020, Aralık). Spor salonlarında egzersiz yapan sporcuların yeni tip koronavirüse (COVID-19) yakalanma kaygılarının incelenmesi. III. International Conference On COVID-19 Studies Kongresine sunulan bildiri, Ankara.

28. Wang, Y., Di, Y., Ye, J. ve Wei, W. (2020). Study on the public psychological states and its related factors during the outbreak of coronavirus disease 2019 (COVID-19) in some regions of China. Psychology, Health \& Medicine, 26(1), 13-22.

29. World Health Organization (WHO) (2020). Announces COVID-19 outbreak a pandemic. Erişim Adresi: https://www.who.int/emergencies/diseases/novel-coronavirus-2019.

30. Yarayan, Y. E. ve Ayan, S. (2018). Farklı takım sporlarında olan sporcuların imgeleme biçimlerinin incelenmesi. Journal of International Social Research, 11(60), 1414-1422.

31. Yarayan, Y. E., Yıldız, A. B. ve Gülşen, D. B. A. (2018). Elit düzeyde bireysel ve takım sporu yapan sporcuların zihinsel dayanıklılık düzeylerinin çeșitli değișkenlere göre incelenmesi. Uluslararası Sosyal Araştırmalar Dergisi, 11(57), 992-999.

32. Yıldırım, A. ve Şimşek H. (2006). Sosyal bilimlerde nitel araştırma yöntemleri. Ankara: Seçkin Yayınevi.

33. Yıldız, A. B., Algün Doğu, G., Parlakkılıç Büyükakgül Ş. ve Yaman Yılmaz, C. (2020). The relationship between athletic mental energy and eating behaviors, Progress in Nutrition, 22(2), e2020017.

34. Yıldız, Y. (2020). Examination of the anxiety situations of catching The new type of coronavirus (COVID-19) in elite Athletes. Journal of Human Sciences, 17(4), 1275-1284. 